Volume 3 Part 2 November I97 I

Journal of Latin American Studies

Cambridge University Press 
lournal of Latin American Situdies is published twice a year under the academic sponsorship of the Centres or Institutes of Latin American Studies at the Universities of Cambridge, Glasgow, Liverpool, London and Oxford.

The scope of the journal is the study of Latin America from the standpoint of the social sciences, including anthropology, archaeology, economics, geography. history, international relations, politics, sociology, etc., though it is not concerned with linguistic or literary studies.

Editorial policy avoids commitment to any political viewpoint or ideology, but welcomes free discussion of such issues in the Latin American context, on the understanding that all responsibility for opinions expressed rests exclusively with the author concerned and not with either the journal or its editors.

EDITORS

HAROLD BLAKEMORE, Secretary of the Institute of Latin Americar Studies, University of London.

CLIFIORD T. SMITH, Professor of Latin American Geography and Director of the Centre for Latin American Studies, University of Liverpool.

\section{EDITORIAL BOARI}

W. C. A T KINSON, Stevenson Professor of Hispanic Studies and Director of the Institute of Latin American Studies, University of Glasgow.

A. R. M. C A R R, Warden of St Antony's College, University of Oxford.

R. A. H U M PHREYS, Professor of Latin American History and Director of the Institute of Latin American Studies, University of London.

(i. W. R I B BANS, Gilmour Professor of Spanish, University of Liverpeol.

I. STREF:T, Lniversity Lecturer in Latin American Studies, University of Cambridge.

\section{SL'BSCRIPTIONS}

lournal of Latin American Studies is published twice a year in May and November. Single parts are $\ell \mathbf{r} .80$ net in U.K. $(\$ 5.50$ in U.S.A.) plus postage. Two parts form a volume. The subscription price of a volume (which includes postage) is E.2.50 net in U.K. (\$8.50 in U.S.A.). Orders may be sent to a bookseller or to the publishers, Cambridge University Press, Bentley House, 200 Euston Road, I.ondon NWr $2 \mathrm{D}) \mathrm{B}$ and 32 East 57th Street. New York, N.Y. 10022.

Advertising. Enquiries about advertising in this journal should be sent to the publishers. 